\title{
Good Religion or Bad Religion: Distanced Church-members and their Perception of Religion and Religious Plurality
}

\author{
Adrian Portmann $^{\mathrm{a}} \&$ David Plüss ${ }^{\mathrm{b}}$ \\ a) Theologische Fakultät, Universität Basel, Switzerland \\ adrian.portmann@bluewin.ch \\ b) Theologische Fakultät, Universität Bern, Switzerland \\ david.pluess@theol.unibe.ch
}

Received 24 June 2011; accepted 10 September 2011

\begin{abstract}
The article presents the findings of a qualitative study that examined the church affiliation and religiosity of distanced church-members as well as their perception of religions and their reaction to religious plurality. It brings forward thirteen patterns of interpretation to which distanced church-members refer in their evaluation of religions and in their dealing with religious plurality. Two types of pattern constellation could be made out and, correspondingly, two groups whose members share the same patterns: the pluralists and the proponents of the traditional. The principal difference between the types can be seen in their dealing with intuitive reactions to, and critical assessments of, religions. Distanced church-members in general show a weak and individualized religiosity, which is nevertheless connected to Christian ideas and symbols. Again, the two groups mentioned above could be found, their main differences being self-reflexivity in the motives for church affiliation, the social and cultural role ascribed to church, the awareness of confessional identity and expectations of tolerance towards other religions.
\end{abstract}

\section{Keywords}

religious plurality, distanced church-members, secularisation, visible religion, tolerance

\section{Introduction}

There is hardly any need to elucidate the plurality of our society and its recent increase. Suffice to say that most diverse lifestyles, values and worldviews, secular as well as religious, are being lived out, cherished and propagated, and that in the field of religion a wide range of different beliefs coexist side by side (Baumann \& Stolz 2009; for the situation in Basel see www.inforel.ch). This increasing plurality can cause irritation and conflict (Wohlrab-Sahr 2003). The more this happens the more important is the question of how we look at 
diversity, how we evaluate it and deal with it. We know pretty well what experts and politicians think about plurality. We also hear what the representatives of the various religions have to say on the issue. However, we know less about how people perceive plurality in their everyday life and how they deal with it - independent of postulations, recommendations and expert advice. This is where our study begins: it enquires how religion comes to the attention of people in everyday life and how they react to different expressions of religion.

The study focuses on the perspective of distanced members of churches, for the purpose of this enquiry understood as people who belong to a church but do not, or hardly, participate in the activities of their congregation (Kretzschmar 2001). The group in question is the largest among the church-members and represents a substantial part of the Swiss population, ${ }^{1}$ but which is nevertheless relatively unknown as to its religious profile. In order to do justice to the heterogeneity of these distanced church-members, the interviewees have been recruited in four different segments. These have been defined in a way that allows for finding people with a more conservative/traditionalist and with a more progressive/modern worldview as well as people of different educational levels. ${ }^{2}$

The enquiry, undertaken within the frame of the Swiss National Science Foundation's National Research Programme 58, has three aims. It intends to

1) find out how distanced church-members perceive religions (their own religion as well as others), how they react to expressions of religion and their public presence, and how they deal with religious plurality;

2) investigate the respondents' religious profile and their relation to the church; and finally to

3) enquire into the relation between the patterns of interpretation and the religious profile.

${ }^{1}$ Stolz et al. (2011, 5-7; 14f) present four religious profiles found in the Swiss population and in the mainline churches. With 66\% among Catholics and 70\% among Protestants the "distanced" constitute by far the largest group. Although Stolz' criteria for the distanced differ from ours, this figures show the importance of this group. The same applies to Germany, cf. Höhmann \& Krech (2006, 143-195) whose study also covers the distanced members' evaluation of other religions (173-177).

${ }_{2}^{2}$ Regarding the educational level we distinguished people with and people without a university of applied sciences or academic degree; regarding the conservative or modern worldview we asked people to answer two questions on the position of women in society and family (cf. Benthaus-Apel 2006, 208). The interviewees were recruited in the four following segments of society: rotary clubs, social democratic party, shooting associations and networks of ecologically minded craftsmen. These four segments served as the sampling frame; within each segment the interviewees were selected via snowball sampling (cf. Merkens 2007, 290-294). 
The study has a qualitative design. Data has been gathered in 24 interviews in the city and region of Basel (Switzerland), six for each of the four segments mentioned above and with an equal number of men and women and of Protestants and Catholics. Among the elements of the interviews were an imaginary walk through Basel with the interviewees talking about where they encounter religion, narratives about experiences with people known personally, and two series of pictures (of religious buildings and clothing among others) shown to the interviewees who were asked to comment. In conducting the interviews we applied methods from the episodic interview (Flick 1995: 124-130) and, as far as the use of pictures was concerned, from the focussed interview (Hopf 2003: 353-355). The interpretation was carried out in a grounded theory framework (Glaser \& Strauss 1967) using especially Flick's method of thematic coding (Flick 1995: 206-211). In this method each unit of each interview is assigned a code or several codes that summarize its meaning. These codes are compared, similar codes are pooled and assigned higherorder codes until the interview's key patterns of interpretation are reconstructed. On this base the different interviews and their patterns are compared and coded again in order to develop the relevant categories and patterns from within the data instead of forcing them on the data from outside.

\section{Evaluation of Religions and Dealing with Religious Plurality}

The analysis of our data revealed thirteen patterns of interpretation shared by all or some distanced church-members and to which they typically refer in their interpretation and judgements. By pattern of interpretation we mean concepts of reality, social constructions and everyday theories that serve as reference for the interpretation of self and world as well as for the orientation of one's actions (Schütz 1974; Lüders \& Meuser 1997).

These patterns will be presented one by one. We begin with patterns serving the evaluation of religions and continue with those relevant for dealing with religious plurality. In a next step we ask in which combination these patterns can be found and which groups or types can be constructed on grounds of the constellations.

\subsection{Patterns of Interpretation Related to the Evaluation of Religions}

How do distanced church-members evaluate religions? The interviews show what the respondents criticise in religions, what strikes them as odd and what they appreciate. In other words: they reveal what, in their eyes, is a good religion or a bad religion. Beyond that, these statements allow the reconstruction 
of patterns of interpretation used for the evaluation of religions. Since these patterns stem form the data and since real people's worldviews seldom are totally stringent the reconstructed patterns can't be expected to be devoid of any inconsistencies. The following patterns have been found:

"Autonomy vs. coercion": the autonomy of individuals is at the core of this pattern. It stresses people's personal freedom to live and believe (or disbelieve) according to their own principles and to decide on their own whether and, in what way, religious rules should be observed. Respondents claim this right for themselves as well as for other people and for adherents of other religions. Religions are expected to respect this autonomy. Moreover, autonomy and emancipation are seen as a value in itself.

The opposite consists of coercion and religious rules that curtail individuals in their autonomy. Religions, religious groups and their protagonists are therefore criticised or rejected as soon as they use coercion, prescribe a certain form of belief or a certain conduct or way of life. The respondents label this not only as coercion, but also as pressure, violence, repression, use of power or legalist positions. Coercion and the endangering of autonomy are seen in two areas: firstly, in situations where strict religious groups or church hierarchies declare certain beliefs as compulsory and, secondly, regarding conduct and way of life. Here it is mainly women and children who are thought to be subjected to male pressure. Coercion is primarily discussed in relation to clothing: rules in this field (for instance, scarves, the clothing of orthodox Jewish children, or the Salvation Army's uniform) arouse suspicions. However, clothes are not seen as unambiguous signs, the respondents are aware of the possibility that the decision to wear a scarf is an expression of autonomy.

With this pattern the respondents primarily stress individual freedom of religion, the negative form (not being forced to do or believe anything against one's will) no less than the positive one (doing or believing whatever one decides to do or believe). This understanding of freedom of religion also protects atheist positions or deviant concepts of belief.

"Private matter vs. interference": this pattern can be understood as a variation of the first. The emphasis lies on the negative aspect, the element of coercion. But coercion is understood in a wider sense: it begins with every form of interference in personal matters. Consequently, the negative form of freedom of religion is stressed.

The positive aspect is weak and rather blurred. Instead of autonomy (which is not regarded as a value in itself) this pattern privileges privacy. Privacy however is not specified further, and has the character of an empty shell.

"Obtrusiveness vs. discretion": this pattern refers to publicly visible religion and the public demeanour of religions and their representatives, 
particularly vis-à-vis non-believers and adherents of other religions. The presence of religions is met with rejection, if it is felt to be besetting without a possibility for elusion. This is especially so, if representatives of religious groups try to force their convictions on someone or display missionary activities. This is considered as obtrusive and is rejected. Some respondents regard this also as an attack on their autonomy, since it indicates that their own religious convictions are not respected.

Conversely, good religion is characterized by discretion. Two things are meant by that: the first is the lack of the obtrusiveness described. The second is the fact that religion is seen primarily as a personal and inner affair that does not need visible signs, is not shown ostentatiously but rather lived out in a discreet way. Visible signs are not usually considered obtrusive per se, but are nevertheless suspected of being superficial.

"Acceptance vs. claim to absoluteness": while the last patterns referred to the demeanour of religions and their representatives, this pattern concerns mainly the attitude towards non-believers and adherents of other religions. Religions are evaluated on the ground of their ability to accept - in their teaching and their practice - other religions and secular convictions as equal. Claims to absoluteness and all forms of religious wiseacres are rejected. The question is whether the religions are perceived as tolerant or intolerant.

"Support of people in need": another criterion for the evaluation of religions is their ability to lead to good deeds. This involves the direct support of people in need. Moreover, it involves the promotion of relevant values, such as the love of one's neighbour or the dignity of each person. Finally, the pattern also encompasses explicitly political actions like the promotion of solidarity or advocacy for marginalized people, for instance, refugees. A good religion according to this pattern is a religion that is socially committed and practises what it preaches.

"Enlightenment, education": good religion is enlightened religion. Religions and their adherents, therefore, should have gone through a process of education enabling a critical distance to one's own tradition and transforming its difficult aspects and moderates its fundamentalist, extreme or fanatic expressions. Education is understood in a broad sense and as such has its own value. It appears eminently important that religions allow and promote education, especially a critical education in religious matters.

Regarding those forms of religion that are considered problematic, and especially of Islam, it is the lack of education that is seen as the cause of the problems. The notion of religion, however, is not essentialist: religions are not expected to remain the same for all times but are seen as open to transformation through education. 
“Beauty vs. ugliness": beauty or ugliness plays a remarkably important role in evaluating religions. This aesthetic category can even unfold normative meanings. Beautiful religions are likely to be seen as good religions while sombre or uniform clothing, to give an example, is repelling and expresses a religion that is rejected. This pattern relates not only to clothing, but also to religious buildings or, more generally, to the style of a religion - the latter links this pattern to the discretion mentioned above.

"Cohesion vs. dissociation": like the support of people in need, this pattern relates to the impact that religions can have on a society. Here it is the question in what way religions influence the social coexistence of different groups. Religions are appreciated, if they foster the cohesion, not only among people from the same congregation, but also among different groups. This includes dialogue and consideration and the building of social networks across denominational boundaries.

The critically assessed opposite is seen in dissociation and an emphasis on boundaries. This is seen mainly in legalistic and narrow religions, especially when they segregate from others and refuse contact with other groups.

"Good religion is assimilated religion": this pattern is also directed against dissociation. Religions perceived as foreign by the interviewees (henceforth referred to as a foreign religion) are criticised, if they segregate and isolate themselves and live completely according to their own rules. Positively evaluated religions, on the other hand, are assimilated to the customs and rules of the host country.

Such assimilation is demanded in different fields: with regards to clothing, the architecture of religious buildings or the status of women. Respondents using this pattern disapprove of buildings that are, in their eyes, too selfassured or ostentatious, and thus lack a minimal degree of humility — it is typically mosques, and especially minarets, that are perceived as belonging to this category. Even respondents who say that all religions should be allowed their place of worship can retain certain prerogatives for the established religions - at least for the time being, since the acceptance of a new religion as to render it established needs some time.

\subsection{Guidelines for Dealing with Plurality}

In the preceding section a number of patterns of interpretation distanced church-members use to evaluate religions have been outlined. All respondents mention certain forms of religion they find irritating, that appear strange to them — or even stronger: that they find annoying or reject altogether — for themselves but also in general, that is, for other people. These forms are criticised not only in foreign religions but also in their own Christian tradition. 
However, the conclusions respondents draw from these evaluations are a different question. Another set of patterns used to frame the dealing with religions and with religious plurality can shed light on these conclusions. These patterns of interpretation have the character of guidelines or normative patterns.

In his theory of toleration Forst (2003: 32-40, 530) mentions three crucial components of the concept of toleration: the rejection of a conviction or practice considered wrong or bad; the acceptance of this rejected conviction or practice on the grounds of other (and more important) reasons; and, finally, the definition of the limits to toleration. In view of this theory, the outlined critique of religions can be identified as the rejection-component, while the patterns of interpretation presented in this chapter concern the acceptancecomponent and the question of limits of acceptance. Nevertheless these patterns are anything but a systematic philosophy of plurality; they reflect in content and structure the views held by the respondents.

"Toleration": asked about their reaction to religious plurality, distanced church-members are quick in asserting that they are tolerant. If they say that synagogues and mosques, turbans and scarves would not bother them, and that everyone must decide alone what church or temple they visit and what they believe, as long as they leave the others alone - then we see a pattern that merely tolerates different religions, but not more. Particularly, no rights are conceded to foreign religions.

"Equal rights": a second pattern includes the above mentioned "toleration", but clearly goes beyond that. Here, positive and negative freedom of religion is upheld. It is said that all religions have rights, and that even those religious expressions have to be accepted that were rejected in a first evaluation. In this perspective, everyone has the right to live their faith according to their decisions and to demonstrate their religion publicly. This refers to religions in general, but also to clothing and buildings. From this point of view, a ban of minarets or burqas is clearly rejected. However, the pattern does not encompass an active engagement with other traditions or their recognition.

The respondents are at least partially aware that there is a tension between toleration and autonomy. The latter basically strengthens the individual freedom of religion, even against one's own collective, while toleration has its emphasis on the collective freedom, even if this can involve constraints on individual autonomy and the rights of individual members of a certain group. Tensions can also manifest themselves in view of other criteria of good religion, shown for instance in the question whether those religions should be tolerated that are themselves intolerant or make claims to absoluteness. In these cases, the respondents' sympathy is clearly on the side of autonomy and 
similar values, yet they do not revoke their stand for equal rights and freedom of religion.

"Interdictions": this pattern points to the opposite direction. Here, toleration is being limited or revoked and interdictions are taken into consideration. This pattern is applied when religions refuse assimilation to the customary ways and rules of the host country or when they do not remain in their private domain but become publicly visible. This becomes clear when we look at the perception and evaluation of clothing and buildings: Muslims may build mosques, but only to a "bearable extent". The prerogatives of the established religions are emphasized. And some of the respondents indicate their approval of the referendum on the ban of minarets that was put to the vote in Switzerland in 2009. At least for some respondents, interdictions appear a meaningful means of religious policy.

"Recognition": this pattern goes beyond toleration and equal rights. It involves respect and estimation and the assumption that foreign religions have their own virtues and merits. On a personal level, this corresponds to the recognition of a person's religious identity, even if it is expressed in a way that is different from one's own.

Two forms of recognition can be found:

Unconditional recognition: religions are recognised in general, in the sense that Islam or any other religion is seen as a legitimate religion or a legitimate cultural expression of religion, or that a foreign religion is said to be the right thing for someone else. Foreign religions are regarded as (theologically) equal and no less legitimate than one's own religion. This corresponds with the above-mentioned rejection of any claim to absoluteness.

Conditional recognition: recognition is referred specifically to certain characteristics or achievements of religions. In this view, religions are recognised because of their humanising potential, or rather: they are recognised insofar as they exploit their potential, have a humanising impact, advocate certain values (such as love of neighbour, solidarity, dignity of each person, reverence for life) and put them into practice. Recognition for religions can also be based on the sincerity and credibility of their adherents. Here recognition is conditional, that is, it depends on certain achievements being accomplished.

It is apparent that religions are mainly recognised for achievements that benefit the society (social, cultural) and only marginally for their religious or spiritual nature proper.

\subsection{Types of Pattern Constellations}

Thirteen patterns have been presented in the last chapters. Of course, these patterns do not have relevance for all distanced church-members. Given the 
Table 1: Two types of pattern constellation: pluralists and proponents of the traditional

\begin{tabular}{|c|c|c|}
\hline & Pluralists & $\begin{array}{l}\text { Proponents of the } \\
\text { traditional }\end{array}$ \\
\hline \multirow{7}{*}{ evaluation of religions } & autonomy vs. coercion & \\
\hline & & $\begin{array}{l}\text { private matter vs. } \\
\text { interference }\end{array}$ \\
\hline & $\begin{array}{l}\text { obtrusiveness vs. } \\
\text { discretion }\end{array}$ & $\begin{array}{l}\text { obtrusiveness vs. } \\
\text { discretion }\end{array}$ \\
\hline & & $\begin{array}{l}\text { good religion is } \\
\text { assimilated religion }\end{array}$ \\
\hline & cohesion vs. dissociation & \\
\hline & enlightenment, education & \\
\hline & support of people in need & $\begin{array}{l}\text { support of people in } \\
\text { need }\end{array}$ \\
\hline \multirow{3}{*}{$\begin{array}{l}\text { dealing with religious } \\
\text { plurality }\end{array}$} & equal rights & \\
\hline & & $\begin{array}{l}\text { toleration } \\
\text { interdictions }\end{array}$ \\
\hline & recognition & \\
\hline
\end{tabular}

heterogeneity of the group this would have been rather astonishing anyway. In what combinations can these patterns be found among our respondents? It becomes apparent that two patterns ("Obtrusiveness vs. discretion" and "Support of people in need") are supported by all respondents and therefore do not contribute to the clarification of the differences in evaluating religions. In two other patterns ("Beauty, sensuality vs. ugliness" and "Acceptance vs. claim to absoluteness") the distribution is too inconsistent as to enable the formation of groups. Based on the analysis of the remaining nine patterns, however, we could build two types of pattern constellation and correspondingly two groups whose members share the same patterns: the pluralists and the proponents of the traditional. Table 1 shows the distribution of patterns.

\section{Group 1: The Pluralists}

Distanced church-members of the pluralist type evaluate religions on grounds of their respect for individual's autonomy (understood as a value in itself), their avoidance of coercion, their support for education and the ability to take criticism and their contribution to the cohesion of different groups in society. 
They also ask whether a religion supports people in need and whether it acts discreetly.

Toleration towards other religions is supported not only in general but also in the case of conflict. Especially with regard to expressions of religion that they find strange or repelling, the members of this group reject interdictions and hold on to the freedom of religion. In addition, they show recognition for other religions, albeit often limited to their performance of certain achievements for society.

Pluralists allow intuitive reactions and critical evaluations of religions and religious phenomena. This, however, they set apart from the legal regulation of things. The gut feeling does not decide on what should be allowed or forbidden. Instead, they balance reasons and concede rights even to those religions that contradict their own notion of a good religion. Here we find a normative attitude that can be described as pluralism - hence the name of the group.

Pluralists constitute the bigger of the two groups: 13 out of 24 respondents belong to this type. A glance at the four underlying segments shows that the group consists of all the well-educated as well as three less educated respondents, while the conservative or modern orientation is of little consequence.

\section{Group 2: Proponents of the Traditional}

Distanced church-members of this type evaluate religions on grounds of their lack of coercion and interference in private matters. With regard to foreign religions they demand assimilation to what they perceive as the customary in Switzerland. They too ask whether a religion supports people in need and whether it acts discreetly.

Members of this type postulate toleration. But this toleration is limited; in the case of conflict restrictions and interdictions are meaningful means. They do not actively advocate interdictions, but when asked (as was the case with the referendum on the ban of minarets) proponents of the traditional are quick in abandoning toleration.

In this type intuitive reactions and critique have a direct impact on ideas about legal regulation of the religious landscape. Correspondingly, it is difficult to uphold toleration or admit rights vis-à-vis of religions contradicting one's own notion of a good religion. Members of this group, therefore, show more difficulties in coping with religious plurality; they tend to withdraw to their own privacy and to those things that in their eyes are traditional, customary or ancestral - hence the name: proponents oft he traditional.

This type is the smaller of the two groups: seven respondents belong to it, while four other respondents correspond to neither type. A glance at the four 
underlying segments shows that the group consists exclusively of less-educated respondents. Again, the conservative or modern orientation is of little consequence.

\subsection{General Observations}

Respondents make use of the described patterns of interpretation and the criteria for good religion, not only when it comes to foreign religions, but also in regard of their own religion. Their own Christian tradition is criticised as severely as other religions, or even more so.

For the respondents, religions are not under general suspicion and their statements (and not only the ones made by the more highly educated interviewees) are mostly rather nuanced. Consequently, we do not find the oftenobserved paradox that people see religions as an ominous thing and at the same time expect them to solve the problems of society, for instance by conveying ethical values.

On the other hand, distanced church-members do not advocate an euphoric understanding of multiculturalism that regards everything and all religions even-handedly and without hesitation as good and enriching. They do not turn a blind eye on what they perceive as problems and do utter critique.

It is not entire religions that are evaluated as good or bad, but certain expressions or tendencies in different religions. In this respect our findings naturally differ from those of Stolz $(2011,29 f)$ who investigates attitudes towards adherents of different religions and the public image of particular religions. This is especially true of the perception of Islam: the respondents approach expressions they classify as fundamentalist with strong repudiation; yet they perceive Islam as a multifaceted entity and do not subsume it indiscriminately, as is often the case in public discourse, under the general rubric of fundamentalist or political Islam.

Altogether the evaluation of religions and the dealing with plurality has little to do with religious or theological questions proper. The positive and negative impact of religions, their contribution to individuals and society are clearly of higher importance. Moreover, questions of style and demeanour have an independent weight in the evaluation of religions.

\section{Personal Religiosity and Church Affiliation}

Distanced church affiliation defines distanced church-members and weak personal religiosity can be expected among them. In the following section, we analyse this general characteristic and assumption and explore particular 
patterns of religiosity and affiliation among both pluralists and proponents of the traditional.

\subsection{Church Affiliation}

Distanced church-members as defined do not tend to participate in worshipservices and other church-organized events. But what is the nature of their relationship to the Church in detail? The following section presents the main elements of our findings.

\section{Patterns of Participation}

Distanced church-members have a complex and strained relationship with the Church. The contacts all our informants have with the Church are reduced to Christmas-Eve and Christmas-services, baptisms, wedding ceremonies and funerals. This corresponds to well-known and common patterns of participation in mainline churches.

All our informants experienced this pattern as self-explanatory and normal. They do not aim to defend it, and further explanations of their behaviour do not seem to be necessary.

A significant part of our sample indicate what we call a 'standby-membership': usually passively behaving church-members, who keep the right to activate their participation occasionally. Others only take notice of particular Church activities: they almost never attend worship, but participate, for instance, in church-organized educational programs.

\section{Explanations for Membership}

Many informants were not able to explain their membership or type of Church affiliation. Only about half of them shared explanations. Among those who did not share, we noted a lack of reasons for keeping church-membership and some of them are inclined towards cancelling their membership.

Pluralists mostly show a well-reflected affiliation with church. Among the proponents of the traditional, reasoning is less distinct and plausible. Some of their explanations point towards an inner conflict between 'head' and 'gut', rational criticism of the Church and emotional bonding to the Church.

\section{Emotional Bonding}

For most informants the Church symbolises tradition, cultural origin and identity. Distanced church-members pursue their membership, even though their personal affiliation with the Church has significantly decreased since their childhood. We were not able to relate increased emotional bonding to the 
Church to recent socio-cultural developments, such as the presence of Muslims in central Europe and the supposedly resulting search for personal religious identity among Christians.

\section{Ambiguous Membership}

Some of our informants showed ambiguous convictions concerning their church-membership. This ambiguity seems to be stronger the more intense a religious socialization they have experienced. The more distanced an informant's social surroundings are, the more rational and detached they describe their relation to the Church.

Bi-confessional marriages and subsequent problems concerning weddings, baptisms and the religious education of children seem to be important factors that lead to the establishment of a more distanced affiliation with the Church.

\subsection{Acknowledgements and Evaluations}

Our data shows the surprising fact that distanced church-members do not evaluate the Church as generally unimportant. In this section we present the various findings about their evaluation of the Church.

\section{Church as Cultural Institution}

A large part of our sample acknowledges the Church as an important cultural institution. As such, it should foster values our informants claim to be in danger of being lost. Church-based education should foremost contribute to the cultivation of such values.

\section{Social Commitment of the Church}

All informants expect social commitment from the Church. Most see this already realized in current activities. Pluralists even think of the Church as the 'glue' of contemporary society. They expect Churches to intervene in situations of crisis and to help people that cannot be reached by state social services. Strikingly, the expectation concerned only established Churches. Free churches and other religious communities are not expected to make social contributions.

\section{Ritual function of the Church}

The Church is widely acknowledged as a ritual institution that deals with marking events, such as deaths and funerals, marriages and baptisms. The ritual function of the Church is seen as a meaningful contribution to society as a whole. 


\section{The discrete aesthetics of the Church(es)}

For many informants, the Church signifies discrete charm and discrete beauty. Inner-city church buildings (as in our case the Basler Minster) are appreciated for their aesthetic value. Church buildings in their visibility and tonality (the sound of bells) are seen as markers of identity. The aesthetics of churches are particularly — and in contrast to other cultural institutions - valued for their simplicity and discreteness.

In addition, some informants point to aesthetic experiences related to the particular atmosphere inside church buildings and the way it engages them in self-reflection or meditation.

\section{The Church as a proponent of liberal religion}

All informants expect the Church to foster liberal forms of religion, which allow different forms of affiliation, different ways of life, different beliefs (even scepticism and atheism), and to tolerate other confessions and religions. Pluralists expect an attitude of appreciation from Churches, whereas for proponents of the traditional the mere toleration of others is sufficient. The Protestant Church is seen as fulfilling these expectations, whereas the Catholic Church is described as tolerant, but to a lesser degree than the Protestant Church, and less appreciating. However, both established Churches are generally perceived as institutions, which do not only tolerate, but also support the separation of State and Church, as well as current developments in science and society. Especially pluralists tend to value both institutions as a bulwark against religious fundamentalism.

\section{Church Criticism}

Many informants openly criticise the Church hierarchy, power structures and backward traditionalism. Repeatedly, topics such as the prohibition of condoms, celibacy and direct engagement in political debates are mentioned. In general, the Catholic Church is more prone to criticism and the group of proponents of the traditional criticise the Church more often than other groups.

Some informants distinguish their criticism between the institutional Church on the one hand, and active church-members on the other. Active church-members are being valued for their convictions, whereas institutional churches are being criticised openly.

\subsection{The Religiousness of Distanced Church-Members}

Distanced church-members are not all just non-religious. They have their own religiosity, as the following analysis of our findings shows. 
Individualized religiousness: the religiousness of distanced church-members is widely independent from institutional religious practice. All informants claimed to show an individual form of religiousness connected with inner experience rather than explicit religious behaviour. However, most of them do relate to the Church and Christianity when it comes to certain topics. Paradoxically, they declare themselves as non-religious, non-practicing or nonbelieving Christians.

Confessionality: confessional identity has very little significance for a part of our informants. Others celebrate their particular confession only on certain occasions, such as Church holidays. In general, proponents of the traditional tend to find less meaning in their confessional identity and have less knowledge about it than pluralists.

Religion as private affair: our informants locate religion merely in the private sphere - many of them do not even talk about religious matters with their relatives. Religion is seen as a discrete area that should not be shown overtly. Proponents of the traditional even take discretion to be a criterion for adapted religion.

Weak religiousness: personal religiousness is generally weak among our informants. They think of themselves as non-religious or barely religious. Most of them relate their attitude to their infrequent religious practice such as attending worship or praying.

A small group acknowledges the importance of religious practice in general, but delegates their actual practice to 'the Churches'.

Religiousness as benevolence: according to our informants, religiousness is often connected with social encounters, graciousness, good deeds and the inclination to help others. As they argue, a religion has to prove its relevance in the ethical, responsible and peaceful conduct of its believers.

For some, religiousness is connected with the respect for the secret and inexplicable powers that lie behind all living and nature (reverence for life). Hence, religiousness is interpreted as main counterpart to a merely scientific world view.

Finally, a few see it as a fascinating topic for discussion. Hence, their 'religious practice' consists of continuous education on, and discussion of, religious topics.

\section{Conclusion}

All distanced church-members evaluate religions on grounds of their obtrusive or discreet demeanour and their support for people in need. A certain accord can also be found in the fact that they reject coercion or interference in private 
matters and uphold autonomy. Apart from that the two types differ from each other. The most important difference can be seen in their different dealing with intuitive reactions to, and critical assessments of, religions: pluralists admit such reactions and assessments, but nevertheless tolerate religions and concede rights even to those religions that contradict their own notion of a good religion. Proponents of the traditional, on the other hand, derive their understanding of how society should be regulated directly and without further pondering from their intuitive reactions and critical assessments or prejudices. Education is the decisive criterion for the respondents' affinity with one of the two types.

Distanced church-members express a weak and individualized religiousness that takes place apart from religious institutions or only relates to them occasionally. It is more or less connected to Christian ideas and symbols. Some of the informants stressed the idea of a 'shapeless' and apersonal transcendence, which can be found, for instance, in divine powers, 'beauty' or a 'higher good'. Conversely, we did not find esoteric forms of religiousness or combinations of different religious traditions ('patchwork religiousness') among our informants. In general, the legitimacy of individualized, autonomous religiousness was never contested, but rather seen as self-evident. We made clear that pluralists and proponents of the traditional differ in their religiousness and their affiliation to the Church. The main points of difference were self-reflexivity in their motives for Church affiliation, the social and cultural role ascribed to the Church, the awareness of confessional identity, and expectations of tolerance towards other religions.

\section{References}

Baumann, Martin / Stolz, Jörg (Hg.) (2009). Eine Schweiz - viele Religionen. Risiken und Chancen des Zusammenlebens, Bielefeld: transcript.

Benthaus-Apel, Friederike (2006). Lebensstilbezogene Zugänge zur Kirchenmitgliedschaft, in: Friedrich, Johannes / Huber, Wolfgang / Steinacker, Peter (Hg.): Kirche in der Vielfalt der Lebensbezüge, Gütersloh, S. 205-236.

Flick, Uwe (1995). Qualitative Forschung. Theorie, Methoden, Anwendung in Psychologie und Sozialwissenschaften, Reinbek bei Hamburg: Rowohlt.

Forst, Rainer (2003). Toleranz im Konflikt. Geschichte, Gehalt und Gegenwart eines umstrittenen Begriffs, Frankfurt/Main: Suhrkamp.

Glaser, Barney / Strauss, Anselm L. (1967). The discovery of Grounded Theory. Strategies for Qualitative Research, Chicago: Aldine.

Höhmann, Peter / Krech Volkhard (2006). Das weite Feld der Kirchenmitgliedschaft. Vermessungsversuche nach Typen, sozialstrukturelle Verortung, alltägliche Lebensführung und religiöse Indifferenz, in: Friedrich, Johannes / Huber, Wolfgang / Steinacker, Peter (Hg.): Kirche in der Vielfalt der Lebensbezüge, Gütersloh, S. 143-195. 
Hopf, Christel (2007). Qualitative Interviews - ein Überblick, in: Flick, Uwe / von Kardorff, Ernst / Steinke, Ines (Hg.): Qualitative Forschung. Ein Handbuch, Reinbek bei Hamburg: Rowohlt, S. 349-360.

Kretzschmar, Gerald (2001). Distanzierte Kirchlichkeit, Neukirchen-Vluyn: Neukirchener Verlag.

Lüders, Christian / Meuser, Michael (1997). Deutungsmusteranalyse, in: Hitzler, Ronald / Honer, Anne (Hg.): Sozialwissenschaftliche Hermeneutik. Eine Einführung, Opladen: Leske und Budrich, S. 57-79.

Merkens, Hans (2007). Auswahlverwahren, Sampling, Fallkonstruktion, in: Flick, Uwe / von Kardorff, Ernst / Steinke, Ines (Hg.): Qualitative Forschung. Ein Handbuch, Reinbek bei Hamburg: Rowohlt, S. 286-299.

Schütz, Alfred (1974). Der sinnhafte Aufbau der sozialen Welt, Frankfurt/Main: Suhrkamp.

Stolz, Jörg et al. (2011). Religiosität in der modernen Welt. Bedingungen, Konstruktionen und sozialer Wandel, Schlussbericht NFP 58, Lausanne: Observatoire des religions en Suisse.

Wohlrab-Sahr, Monika (2003). Politik und Religion. Diskretes Kulturchristentum als Fluchtpunkt europäischer Gegenbewegungen gegen einen "ostentativen” Islam, in: Nassehi, Armin I Schroer, Markus (Hg.): Der Begriff des Politischen (Soziale Welt. Sonderband 14), BadenBaden: Nomos, S. 273-297. 